\title{
Pengaruh Kepemimpinan, Efikasi Diri dan Lingkungan Kerja Non- Fisik Terhadap Kinerja Karyawan pada Bank Syariah Bumi Artha Sampang Kebumen
}

\author{
Mukhamad Wahyudin', Prihartini Budi Astuti ${ }^{2}$ \\ ${ }^{1}$ Sekolah Tinggi Ilmu Ekonomi Putra Bangsa \\ ${ }^{2}$ Sekolah Tinggi Ilmu Ekonomi Putra Bangsa \\ Email: mukhamadwahyudin28@gmail.com
}

\section{ARTICLE INFO}

Article History:

Received: March 10th 2020

Accepted: March 11th 2020

Published: June 30th 2020

Keywords :

Kepemimpinan, efikasi diri, lingkungan kerja non fisik, kinerja

\begin{abstract}
Penelitian ini bertujuan untuk mengetahui pengaruh Kepemimpinan, Efikasi Diri, dan Lingkungan Kerja Non Fisik terhadap Kinerja karyawan pada Bank Syariah Bumi Artha Sampang Kebumen. Data sampel yang diambil pada penelitian ini yaitu karyawan pada Bank Syariah Bumi Artha Sampang Kebumen yang berjumlah 34 karyawan sebagai responden. Instrumen atau alat pengumpulan data pada penelitian ini adalah menggunakan angket/kuesioner. Alat analisis data yang digunakan pada penelitian ini yaitu menggunakan analisis regresi linier berganda.. Teknik analisis data yang digunakan antara lain analisis kualitatif dan analisis kuantitatif yang terdiri dari uji validitas, uji reliabilitas, uji $\mathrm{t}$, uji F, analisis regresi linier berganda (skala likert). Dari hasil pembuktian hipotesis pertama bahwa Kepemimpinan secara parsial mempunyai pengaruh yang signifikan terhadap Kinerja. Dari hasil hipotesis ke dua bahwa Efikasi diri secara parsial mempunyai pengaruh yang signifikan terhadap Kinerja. Dari hasil pembuktian hipotesis ketiga bahwa Lingkungan Kerja Non Fisik secara parsial mempunyai pengaruh yang signifikan terhadap Kinerja. Dari hasil hipotesis keempat Kepemimpinan, Efikasi diri, dan Lingkungan Kerja Non Fisik secara simultan mempunyai pengaruh yang signifikan terhadap Kinerja.
\end{abstract}

\section{Pendahuluan}

Bank Syariah Bumi Artha Sampang Kebumen adalah perusahaan atau lembaga keuangan mikro dengan tujuan mendorong pengembangan usaha mikro meminjamkan dana tunai. Dalam pelaksanaannya, lembaga keuangan maupun organisasi manapun sangatlah membutuhkan sumber daya manusia yang unggul demi tercapainya kinerja yang baik dan berprestasi. Pada era globalisasi pada saat ini perkembangan bisnis keuangan sangat pesat. Banyaknya persaingan antara perusahaan merupakan salah satu faktor ketatnya persaingan dalam bisnis keuangan. Pihak manajemen Bank Syariah Bumi Artha Sampang Kebumen dituntut untuk bisa berkembang dengan baik dan bersaing dengan cara meningkatkan kinerja karyawan, sehingga dalam pencapaian target perusahaan dapat terealisasi. 
Menurut Handoko (2010:69), banyak faktor yang dimungkinkan mempengaruhi baik buruknya kinerja karyawan dalam melaksanakan tugas dan tanggung jawabnya, yang meliputi faktor internal maupun eksternal. Faktor internal dapat berupa skill karyawan, sedangkan faktor eksternal dapat berupa kepemimpinan, efikasi diri, dan lingkungan kerja. Berdasarkan uraian tersebut dapat dikatakan bahwa faktor kepemimpinan, efikasi driri, dan lingkungan kerja merupakan beberapa faktor yang dimungkinkan mempengaruhi baik buruknya kinerja karyawan pada Bank Syariah Bumi Artha Sampang Kebumen yang terletak di JL. Pemuda No.32.

Bank Syariah Bumi Artha Sampang Kebumen yang terletak di JL. Pemuda No.32 mengalami penurunan kinerja karyawannya dengan tidak tercapainya target-target yang sudah ditentukan. Berbagai upaya telah dilakukan pihak perusahaan Bank Syariah Bumi Artha Sampang Kebumen dengan cara melakukan sosialisasi produk terhadap masyarakat. Berikut ini adalah data pencapaian target Bank Syariah Bumi Artha Sampang Kebumen.

Berikut ini adalah data pencapaian target Bank Syariah Bumi Artha Sampang Kebumen Tabel 1. pencapaian target karyawan bank syariah bumi artha sampang Kebumen tahun 2016-2018

\begin{tabular}{ccc}
\hline TAHUN & TARGET & REALISASI \\
\hline 2016 & 900 Nasabah & 700 Nasabah \\
2017 & 850 Nasabah & 650 Nasabah \\
2018 & 800 Nasabah & 600 Nasabah \\
\hline
\end{tabular}

Sumber data: Bank Syariah Bumi Artha Sampang Kebumen

Karyawan Bank Syariah Bumi Artha Sampang Kebumen dalam mencari nasabah peminjaman dana tunai mengalami penurunan kinerja dengan hasil target team karyawan pada Bank Syariah Bumi Artha Sampang Kebumen yang belum pernah tercapai atau terealisasi oleh karyawannya. Dari data target dan data yang sudah terealisasi karyawan pada Bank Syariah Bumi Artha Sampang Kebumen pada tahun 2016 sejumlah 900 Nasabah dan hanya terealisasi 700 nasabah. Sedangkan pada tahun 2017 karyawan pada Bank Syariah Bumi Artha Sampang Kebumen menurunkan target team karena tahun 2016 tidak tercapai dari target 900 nasabah sebelumnya ditahun 2017 diturunkan menjadi 850 nasabah dan hanya terealisasi 650 nasabah. Pada tahun berikutnya yaitu tahun 2018 Bank Syariah Bumi Artha Sampang Kebumen kembali menurunkan target dari 850 nasabah menjadi 800 nasabah. Karyawan pada Bank Syariah Bumi Artha Sampang Kebumen hanya mampu memperoleh atau merealisasi 600 nasabah dari target perusahaan 800 nasabah. Pihak manajemen perlu mencari solusi agar target yang ditetapkan perusahaan mampu tercapai atau terealisasi oleh karyawan.

Dari data target tersebut penting untuk dievaluasi kinerja karyawan pada Bank Syariah Bumi Artha Sampang Kebumen dari internal dengan mengevaluasi bagaimana kepemimpinan yang diterapkan pada karyawan pada Bank Syariah Bumi Artha Sampang Kebumen karena kepemimpinan yang baik akan mempengaruhi tingkat kinerja karyawannya. Selain kepemimpinan yang harus di evaluasi, efikasi diri atau kemampuan individu dari masing- masing karyawan karyawan pada Bank Syariah Bumi Artha Sampang Kebumen perlu ditingkatkan lagi. Efikasi diri atau kemampuan diri sendiri masing-masing karyawannya sangat menentukan hasil kinerja yang telah ditargetkan oleh pihak perusahaan. Lingkungan kerja non fisik juga merupakan faktor yang perlu dievaluasi untuk meningkatkan kinerja karyawan, karena lingkungan kerja non fisik yang kurang kondusif, tidak sehat, hubungan antar karyawan kurang harmonis sangat mempengaruhi kinerja karyawan. 
Menarik mengangkat topik tentang kepemimpinan, efikasi diri, dan lingkungan kerja sebagai tolak ukur kinerja, karena pada dasarnya setiap aktivitas kerja selalu tertuju pada hasil atau kinerja karyawan sebagai tolak ukur baik tidaknya kondisi suatu organisasi yang terjadi pada suatu perusahaan.

\section{Kajian Teori dan Telaah Literatur}

\section{Kinerja}

Landasan yang sesungguhnya dalam suatu organisasi adalah kinerja. Pengertian kinerja Menurut Simanjuntak (2015;110), kinerja adalah tingkat pencapaian hasil atas pelaksanaan tugas tertentu. Kinerja perusahaan adalah tingkat pencapaian hasil dalam rangka mewujudkan tujuan perusahaan. Indikator kinerja karyawan dikemukakan sebagai berikut:

a. Quantity of work: jumlah kerja yang dilakukan dalam suatu periode yang ditentukan.

b. Quality of work: kualitas kerja yang dicapai berdasarkan syarat-syarat kesesuaian dan kesiapannya.

c. Job knowledge: luasnya pengetahuan mengenai pekerjaan dan ketrampilannya.

d. Creativeness: keaslian gagasan-gagasan yang dimunculkan dan tindakan-tindakan untuk menyelesaikan persoalan-persoalan yang timbul.

e. Coorperation: kesediaan untuk bekerjasama dengan orang lain atau sesame anggota organisasi.

f. Dependability: kesadaran untuk dapat dipercaya dalam hal kehadiran dan penyelesaian kerja.

g. Intiative: semangat untuk melaksanakan tugas-tugas baru dalam memperbesar tanggung jawabnya.

h. Personal qualities: menyangkut, kepribadian, kepemimpinan, keramahan, dan intregitas pribadi (Rivai dan Basri, 2013: 85-86).

\section{Kepemimpinan}

Menurut Robbins (2006:432) kepemimpinan adalah kemampuan untuk mempengaruhi kelompok menuju pencapaian sasaran. Berdasar uraian diatas, maka kepemimpinan adalah kemampuan mempengaruhi, menggerakkan, penyelaras dan mengarahkan serta mengintegrasikan aktivitas-aktivitas suatu tindakan pada diri seseorang atau kelompok untuk bekerja sama dan mau bekerja secara produktif untuk tujuan dalam situasi tertentu pula. Menurut Wahjosumidjo (2013:154) secara garis besar indikator kepemimpinan
a. Bersikap adil
b. Memberikan sugesti
c. Mendukung tercapainya tujuan
d. Menciptakan rasa aman
e. Sumber inspirasi
f. Bersikap menghargai

\section{Efikasi diri}

Bandura (dalam Irwansyah, 2013 : 116) mengartikan self efficacy sebagai pertimbangan seseorang terhadap kemampuannya dalam mengorganisasikan, melaksanakan tindakantindakan yang diperlukan untuk mencapai prestasi tertentu.

Menurut Smith, (dalam Sya'dullah, 2011:17) indikator dari efikasi diri mengacu pada dimensi efikasi diri yaitu level, strength, dan generality, dengan melihat tiga dimensi ini maka terdapat beberpa indikator dari efikasi diri yaitu: 
a. Yakin dapat melakukan tugas tertentu; individu yakin dapat melakukan tugas tertentu yang mana individu sendirilah yang menetapkan tugas (target) apa yang harus diselesaikan.

b. Yakin dapat memotivasi diri untuk melakukan tindakan yang diperlukan untuk menyelesaikan tugas.

c. Yakin bahwa individu mampu berusaha dengan keras, gigih dan tekun dalam rangka menyelesaikan tugas dengan menggunakan segala daya yang dimiliki.

d. Yakin bahwa dirinya mampu bertahan mengahdapi hambatan dan kesulitan yang muncul serta mampu bangkit dari kegagalan.

e. Yakin dapat menyelesaikan permasalahan diberbagai situasi atau kondisi.

\section{Lingkungan kerja non-fisik}

Menurut Sedarmayanti (2010:13-14) , lingkungan kerja non fisik adalah semua keadaan yang terjadi yang berkaitan dengan hubungan kerja, baik hubungan dengan atasan maupun hubungan dengan bawahan sesame rekan kerja maupun hubungan dengan bawahan.

Indikator-indikator lingkungan kerja non fisik oleh DeStefano (2006) yaitu sebagai berikut:

a. Prosedur Kerja, adalah rangkaian tata pelaksanaan kerja yang di atur secara berurutan, sehingga terbentuk urutan kerja secara bertahap dalam menyelesaikan suatu pekerjaan.

b. Standar Kerja, adalah persyaratan tugas, fungsi atau perilaku yang ditetapkan oleh pemberi kerja sebagai sasaran yang harus dicapai oleh seorang karyawan.

c. Pertanggung jawaban Supervisor, Tanggung jawab seorang supervisor untuk menyusun tugas karyawan agar dapat dikerjakan secara efektif dan adil. Supervisor juga bertanggung jawab mengadakan evaluasi karyawan untuk menjamin pencapaian sasaran yang sudah ditetapkan oleh perusahaan.

d. Kejelasan Tugas, yaitu sejauh mana pekerjaan itu menuntut diselesaikannya seluruh potongan kerja secara utuh dan dapat dikenali oleh karyawan. Dalam hal ini karyawan dituntut untuk memahami dan mampu melaksanakan pekerjaan mereka berdasarkan instruksi dari atasan.

e. Sistem Penghargaan, Sistem imbalan atau sistem penghargaan (reward system) adalah sebuah program yang digunakan untuk mengenali prestasi individual karyawan, seperti pencapaian sasaran atau proyek atau penggunaan ide-ide kreatif.

f. Hubungan antar Karyawan, yaitu hubungan dengan rekan kerja harmonis dan tanpa ada saling intrik diantara sesama rekan kerja. Salah satu faktor yang mempengaruhi karyawan tetap tinggal dalam satu organisasi adalah adanya hubungan yang harmonis diantara rekan kerja.

\section{Kerangka teori}

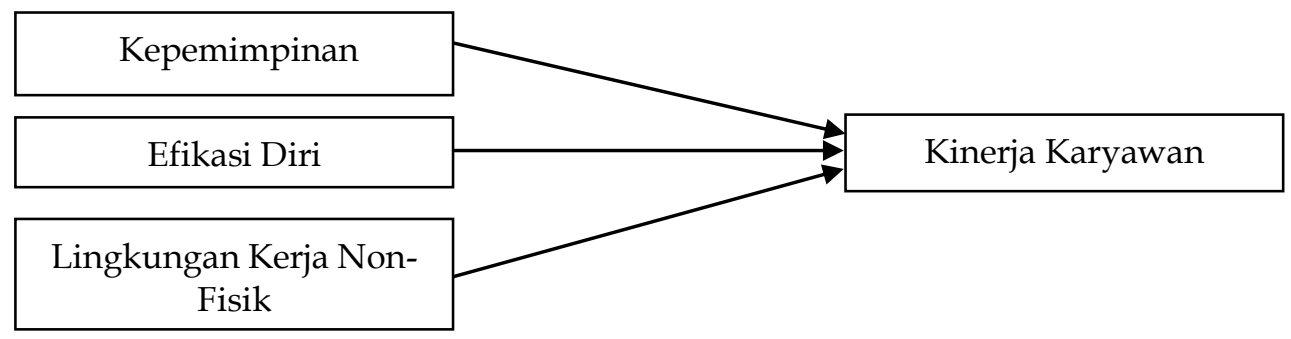

Gambar 1. Model Penelitian 


\section{Hipotesis}

Hipotesis dalam penelitian ini adalah :

$\mathbf{H}_{1}$ : Terdapat pengaruh secara parsial variabel kepemimpinan terhadap kinerja karyawan pada Bank Syariah Bumi Artha Sampang Kebumen.

$\mathbf{H}_{2}$ : Terdapat pengaruh secara parsial variabel efikasi diri terhadap kinerja karyawan pada Bank Syariah Bumi Artha Sampang Kebumen.

$\mathbf{H}_{3}$ : Terdapat pengaruh secara parsial variabel lingkungan kerja non fisik terhadap kinerja karyawan pada Bank Syariah Bumi Artha Sampang Kebumen.

$\mathbf{H}_{4}$ : Terdapat pengaruh secara simultan variabel kepemimpinan, efikasi diri, dan lingkungan kerja non fisik terhadap kinerja karyawan pada Bank Syariah Bumi Artha Sampang Kebumen.

\section{Metode Penelitian}

\section{Teknik pengumpulan data}

Pengumpulan data yang dimaksud untuk memperoleh bahan-bahan yang relevan dan akurat melalui :

a. Observasi yaitu dengan melakukan pengamatan secara langsung pada obyek penelitian.

b. Kuesioner yaitu dengan membuat sejumlah daftar pertanyaan yang berhubungan dengan masalah yang diteliti dan diajukan kepada responden. Jawaban setiap item instrument menggunakan skala likert mempunyai gradasi dari sengat positif sampai sangat negatif, Sugiyono (2008: 143).

1. Sangat Setuju skor $=4$

2. Setuju skor $=3$

3. Tidak Setuju skor $=2$

4. Sangat Tidak Setuju skor $=1$

c. Studi Pustaka, yaitu dengan mengambil teori-teori yang ada pada literatur yang berhubungan dengan masalah yang diteliti.

\section{Teknik analisis data}

Dalam perhitungan pengolahan data regresi linier berganda peneliti mempergunakan alat bantu yang berupa program aplikasi komputer yaitu SPSS for windows versi 22.

\section{Hasil dan Pembahasan}

\section{Regresi linier berganda}

Berdasarkan hasil dari perhitungan dengan menggunakan bantuan program SPSS maka diketahui hasil uji t regresi linier berganda adalah sebagai berikut:

$Y=9,124+0,305 X_{1}+0,562 X_{2}+0,209 X_{3}+\epsilon_{1}$

\section{Uji hipotesis}

a. Pengaruh Kepemimpinan terhadap Kinerja

Berdasarkan analisis untuk kepemimpinan mempunyai pengaruh yang signifikan terhadap Kinerja, karena nilai $t_{\text {hitungsebesar 3,147>t }} t_{\text {tabel }}$ sebesar 2,039. Besarnya pengaruh kepemimpinan terhadap Kinerja 0,305 atau 30,5\%.

b. Penngaruh Efikasi Diri terhadap Kinerja

Berdasarkan analisis untuk variabel Efikasi diri mempunyai pengaruh yang signifikan terhadap Kinerja, karena nilai $t_{\text {hitung }}$ sebesar 3,799>t tabel sebesar 2,039. Besarnya pengaruh Efikasi diri terhadap Kinerja 0,562 atau 56,2\%.

c. Penngaruh Lingkungan Kerja Non Fisik terhadap Kinerja 
Berdasarkan analisis untuk variabel Lingkungan kerja non fisik mempunyai pengaruh yang signifikan terhadap Kinerja, karena nilai $t_{\text {hitung }}$ sebesar 2,326 $>t_{\text {tabel }}$ sebesar 2,039. Besarnya pengaruh Lingkungan kerja non fisik terhadap Kinerja 0,209 atau 20,9\%..

d. Pengaruh kepemimpinan, efikasi diri dan lingkungan kerja non fisik secara simultan terhadap kinerja karyawan pada Bank Syariah Bumi Artha Sampang Kebumen.

Berdasarkan analisis diperoleh $\mathrm{F}_{\text {hitung }}$ sebesar 9,398 dengan tingkat signifikansi 0.000, karena probabilitas 0.000 jauh lebih kecil dari 0,050, maka bisa dikatakan bahwa variabel kepemimpinan $\left(X_{1}\right)$, efikasi diri $\left(X_{2}\right)$, dan lingkungan kerja non fisik $\left(X_{3}\right)$ berpengaruh signifikan terhadap kinerja $(Y)$ secara simultan

\section{Koefisien determinasi}

Nilai koefisien determinasi Adjusted R Square diperoleh 0,433 artinya 43,3\% kinerja di pengaruhi oleh variabel kepemimpinan, efikasi diri, dan lingkungan kerja non fisik, sedangkan sisanya $56,7 \%(100 \%-43,3 \%)$ disebabkan oleh variabel lain yang tidak ada dalam penelitian ini.

\section{Pembahasan}

\section{Pengaruh persepsi kepemimpinan terhadap kinerja}

Berdasarkan analisis variabel kepemimpinan mempunyai pengaruh yang signifikan terhadap Kinerja. Hal ini berarti semakin baiknya kepemimpinan pada Bank Syariah Bumi Artha Sampang Kebumen, maka semakin baik juga kinerja karyawan pada Bank Syariah Bumi Artha Sampang Kebumen. Besarnya pengaruh kepemimpinan terhadap Kinerja 0,305 atau 30,5\%. Bagi pimpinan Bank Syariah Bumi Artha Sampang Kebumen diharap untuk memperhatikan kepemimpinan yang diterapkan pada Bank Syariah Bumi Artha Sampang Kebumen, karena faktor kepemimpinan yang baik dapat meningkatkan kinerja karyawan pada Bank Syariah Bumi Artha Sampang Kebumen. Kepemimpinan yang baik yang diterapkan pada perusahaan akan meningkatkan kinerja karyawan seperti kepemimpinan yang bersifat adil, memberikan sugesti, mendukung tercapainya tujuan, menciptakan rasa aman, sumber inspirasi, bersikap menghargai.

Hasil penelitian ini diperkuat Penelitian yang dilakukan oleh Maelul Hashifi (2010) dengan judul" Pengaruh Kepemimpinan dan Lingkungan Kerja Terhadap Kinerja Karyawan", hasil penelitian menunjukan adanya hubungan positif persepsi kepemimpinan terhadap kinerja.

Penelitian yang dilakukan oleh Feni Septi Aryanti (2017), dengan judul Pengaruh Kepemimpinan, Motivasi, dan Lingkungan Kerja terhadap Kinerja Karyawan Pada PT. Mitra Bisnis Keluarga Ventura Kroya, hasil penelitian menunjukan adanya hubungan positif kepemimpinan terhadap kinerja

2. Pengaruh efikasi diri terhadap kinerja

Berdasarkan analisis untuk variabel efikasi diri mempunyai pengaruh yang signifikan terhadap Kinerja. Hal ini berarti dengan semakin baiknya efikasi diri karyawan pada Bank Syariah Bumi Artha Sampang Kebumen, maka semakin baik juga kinerja karyawan pada Bank Syariah Bumi Artha Sampang Kebumen. Besarnya pengaruh efikasi diri terhadap kinerja 0,562 atau 56,2\%. Pihak manajemen diharap untuk memperhatikan faktor efikasi diri pada karyawan Bank Syariah Bumi Artha Sampang Kebumen. Efikasi diri disini yaitu kemampuan setiap individu karyawan untuk menunjukan kemampuannya yang dapat berkonstribusi bagi Bank Syariah Bumi Artha Sampang Kebumen. Pihak manajemen Bank Syariah Bumi Artha Sampang Kebumen dituntut untuk mampu meningkatkan efikasi diri karyawan seperti dilakukan pelatihan kerja khusus, atau training yng lebih intensif supaya karyawan yakin dapat melakukan tugas tertentu, yakin dapat memotivasi diri untuk melakukan 
tindakan yang diperlukan untuk menyelesaikan tugas, yakin bahwa individu mampu berusaha dengan keras, gigih dan tekun dalam rangka menyelesaikan tugas dengan menggunakan segala daya yang dimiliki, yakin bahwa dirinya mampu bertahan mengahdapi hambatan dan kesulitan yang muncul serta mampu bangkit dari kegagalan, yakin dapat menyelesaikan permasalahan diberbagai situasi atau kondisi sehingga karyawan mampu menunjukan kemampuannya yang dapat berkonstribusi bagi Bank Syariah Bumi Artha Sampang Kebumen.

Hasil penelitian ini diperkuat Penelitian yang dilakukan oleh Dennis (2018), dengan judul Pengaruh Kepemimpinan, Efikasi Diri, dan Lingkungan Kerja terhadap Kinerja Karyawan PT. Nusantara Sakti. Hasil penelitian menunjukan adanya hubungan positif efikasi diri terhadap kinerja karyawan.

Penelitian yang dilakukan oleh Stevani (2016) dengan judul Pengaruh Persepsi kepemimpinan, efikasi diri terhadap Kinerja Pada PT. Bintang Pasaman Finance. Hasil penelitian menunjukan adanya hubungan positif efikasi diri terhadap kinerja.

\section{Pengaruh lingkungan kerja non fisik terhadap kinerja}

Berdasarkan analisis untuk variabel Lingkungan kerja non fisik mempunyai pengaruh yang signifikan terhadap Kinerja. Hal ini berarti semakin baik lingkungan kerja non fisik dalam sebuah organisasi pada Bank Syariah Bumi Artha Sampang Kebumen, maka semakin baik juga kinerja karyawan pada Bank Syariah Bumi Artha Sampang Kebumen, artinya bahwa peran lingkungan kerja non fisik berpengaruh terhadap kinerja karyawan. Besarnya pengaruh lingkungan kerja non fisik terhadap Kinerja 0,209 atau 20,9\%. Pihak manajeme diharap untuk memperhatikan faktor lingkungan kerja non fisik pada Bank Syariah Bumi Artha Sampang Kebumen, karena faktor lingkungan kerja non fisik yang baik dapat meningkatkan kinerja karyawan pada Bank Syariah Bumi Artha Sampang Kebumen. Lingkungan kerja non fisik yang baik akan meningkatkan kinerja karyawan, seperti prosedur kerja, standar kerja, pertanggung jawaban supervisor, kejelasan tugas, sistem penghargaan, hubungan antar karyawan. Hasil penelitian ini diperkuat Penelitian yang dilakukan oleh Nanang Mardani (2017), dengan judul Pengaruh Kepemimpinan, Motivasi, dan Lingkungan Kerja terhadap Kinerja Karyawan Pada Bank BTN Kebumen. hasil peelitian menunjukan adanya hubungan positif lingkungan kerja terhadap kinerja karyawan.

\section{Penutup dan Saran}

\section{Simpulan}

a. Kepemimpinan mempunyai pengaruh yang signnifikan terhadap kinerja karyawan pada Bank Syariah Bumi Artha Sampang Kebumen. Artinya peran kepemimpinan dalam penelitian ini sangat berpengaruh terhadap kinerja karyawan pada Bank Syariah Bumi Artha Sampang Kebumen dengan dibuktikannya hasil diatas, bahwa kepemimpinan yang baik akan berdampak pada kinerja karyawan pada Bank Syariah Bumi Artha Sampang Kebumen, begitu juga sebaliknya kepemimpinan yang kurang baik akan berakibat pada penurunan kinerja karyawan.

b. Efikasi diri mempunyai pengaruh yang signnifikan terhadap kinerja karyawan pada Bank Syariah Bumi Artha Sampang Kebumen. Efikasi diri disini yaitu kemampuan kerja diri sendiri atau kemampuan kerja setiap karyawannya, artinya peran efikasi diri dalam penelitian ini sangat berpengaruh terhadap kinerja karyawan pada Bank Syariah Bumi Artha Sampang Kebumen dengan dibuktikannya hasil diatas, bahwa efikasi diri yang tinggi akan berdampak pada hasil kinerja karyawan pada Bank Syariah Bumi Artha Sampang Kebumen begitu juga sebaliknya motivasi kerja yang kurang baik akan berakibat pada penurunan kinerja karyawan. 
c. Lingkungan kerja non fisik mempunyai pengaruh yang signnifikan terhadap kinerja karyawan pada Bank Syariah Bumi Artha Sampang Kebumen. Artinya peran lingkungan kerja non fisik dalam penelitian ini sangat berpengaruh terhadap kinerja karyawan pada Bank Syariah Bumi Artha Sampang Kebumen dengan dibuktikannya hasil diatas, bahwa lingkungan kerja non fisik yang baik akan berdampak pada kinerja karyawan pada Bank Syariah Bumi Artha Sampang Kebumen begitu juga sebaliknya lingkungan kerja non fisik yang kurang baik akan berakibat pada penurunan kinerja karyawan.

d. Kepemimpinan, efikasi diri dan lingkungan kerja non fisik mempunyai pengaruh terhadap kinerja karyawan Bank Syariah Bumi Artha Sampang Kebumen. Artinya peran ketiga variabel tersebut dalam penelitian ini sangat penting untuk meningkatkan kinerja karyawan pada Bank Syariah Bumi Artha Sampang Kebumen.

e. Berdasarkan hasil analisis variabel kepemimpinan, efikasi diri, dan lingkungan kerja non fisik variabel yang berpengaruh paling dominan terhadap kinerja yaitu variabel efikasi diri, variabel yang berpengaruh kedua yaitu kepemimpinan dan variabel yang berpengaruh paling kecil yaitu variabel lingkungan kerja non fisik.

\section{Keterbatasan penelitian}

a. Penelitian ini hanya terbatas pada variabel kepemimpinan, efikasi diri, lingkungan kerja non fisik, dan kinerja karyawan pada Bank Syariah Bumi Artha Sampang Kebumen.

b. Variabel yang diteliti masih dirasa belum cukup untuk mengukur faktor-faktor yang mempengaruhi kinerja, sehingga untuk penelitian lebih lanjut perlu menambahkan variabel lain yang dapat mempengaruhi kinerja seperti lingkungan kerja fisik, kompensasi, insentif, beban kerja, dan lain sebagainya.

\section{Referenasi}

Arikunto, S. (2002). Produser Penelitian Suatu Pendekatan Praktek. Jakarta: PT. Rineka Cipta.

Aryanti, F. S. (2017). Analisis Pengaruh Gaya Kepemimpinan, Motivasi, dan Lingkungan Kerja terhadap Kinerja Karyawan. Skripsi Sarjana. Sekolah Tinggi Ilmu Ekonomi Putra Bangsa Kebumen.

Dennis. (2018). Pengaruh Kepemimpinan, Efikasi Diri, dan Lingkungan Kerja terhadap Kinerja Karyawan PT. Nusantara Sakti. Skripsi Sarjana. Sekolah Tinggi Ilmu Ekonomi Putra Bangsa Kebumen.

Endah. (2018). Pengaruh Kepemimpinan, Motivasi, dan Lingkungan Kerja terhadap Kinerja karyawan PT. Mandala Finance. Skripsi Sarjana. Sekolah Tinggi Ilmu Ekonomi Putra Bangsa Kebumen.

Faiqoh. (2009). Analisis Pengaruh Kepemimpinan, Motivasi, Dan Disiplin Kerja Terhadap Kinerja Tenaga Kependidikan Di SMK Batik 2 Kebumen. Skripsi Sarjana. Sekolah Tinggi Ilmu Ekonomi Putra Bangsa Kebumen.

Ghozali, I. (2006). Aplikasi Analisis Multivariat Dengan Program IBM SPSS 21.Cetakan IV. Semarang: Badan Penerbitan Universitas Dipenogoro.

Gomes, F. C. (2002). Manajemen Sumber Daya Manusia, edisi pertama. Yogyakarta: Andi.

Hadi, S. (2006). Metodologi Penelitian Kuantitatif untuk Akuntansi dan Keuangan. Yogyakarta: Ekonisia. 
Hadi, Sutrisno. 2004. Metodologi Penelitian Administrasi Untuk Ekonomi dan Bisnis. Edisi 1. Yogyakarta : BPFE.

Handoko, T. H. (2010). Manajemen Personalia dan Sumber Daya Manusia. Yogyakarta: BPFE.

Hashifi, M. (2010). Analisis Pengaruh Persepsi Kepemimpinan dan Lingkungan Kerja terhadap Kinerja Karyawan. Skripsi Sarjana. Sekolah Tinggi Ilmu Ekonomi Putra Bangsa Kebumen.

Hasibun, M. S. P. (2011). Organisasi dan Motivasi, Dasar Peningkatan Produktivitas Jakarta: Bumi Aksara

Kusworo. (2009). Analisis Pengaruh Kepemimpinan Dan Lingkungan Kerja terhadap Kinerja Karyawan di SMK Alfalah Somelangu Sumberadi Kebumen. Skripsi Sarjana. Sekolah Tinggi Ilmu Ekonomi Putra Bangsa Kebumen.

Laksana, F. (2008). Manajemen Pemasaran: Pendekatan Praktis. Yogyakarta: Graha Ilmu.

Mardani, N. (2017). Analisis Pengaruh Gaya Kepemimpinan, Motivasi dan Lingkungan Kerja Terhadap Kinerja Karyawan. Skripsi Sarjana. Sekolah Tinggi Ilmu Ekonomi Putra Bangsa Kebumen.

Martoyo, S. (2011). Manajemen Sumber Daya Manusia, Yogyakarta: BPFE.

Purwoto, A. (2009). Panduan Laboratorium Statistik Inferensial. Jakarta: Grasindo.

Sondang, P. S. (2003). Teori dan Praktek Kepemimpinan. Jakarta: PT Rineka Cipta.

Stevani. (2016). Analisis Pengaruh Persepsi Kepemimpinan, dan Self Efficacy, terhadap Kinerja Karyawan. Skripsi Sarjana. Sekolah Tinggi Ilmu Ekonomi Panca Setia.

Sudarmanto, R. G. (2005). Analisis Regresi Linear Ganda Dengan SPSS. Yogyakarta: Graha Ilmu.

Yuki, G. (1994). Kepemimpinan Dalam Organisasi. Edisi Bahasa Indonesia. Jakarta: Prenhallindo. 